\title{
Assessment of Feeding and Mortality Pattern among Children
}

\author{
Neha Kapoor ${ }^{1}$, Rajni Thapa ${ }^{2}$ \\ ${ }^{1}$ Nursing Tutor SMVDCoN Katra J\&K. \\ ${ }^{2}$ Asst.Prof. SMVDCoN Katra J\&K
}

\begin{abstract}
Several programmes have been implemented by Government of India along with WHO and UNICEF to improve the health status of infants. For the effective child health care delivery. Information regarding infant feeding practices and pattern of morbidity is important. This study was done to describe selected newborn and infant feeding practices, morbidity pattern and care given during the episodes of illness in DM Colony UT. The objectives of the study were to study the feeding practices \& morbidity pattern of children. A house to house survey was conducted \& systemic random sampling method was adopted for the study. Total 101 subjects were enrolled to collect data. Results of the study concluded that the majority of the delivery took place in hospital and mothers initiated breast feeding within one hour of delivery. Approximately half of the caregivers give prelacteal feed to the child. Complementary feeding was started at or after 6 months of age of the child. Majority of the children birth weight was in normal range and $1 / 4^{\text {th }}$ of the child suffered from problem, mainly jaundice at the time of birth. Frequently occurring morbidities in children were diarrhoea, acute respiratory tract infections and conjunctivitis.
\end{abstract}

Keywords: child morbidity, feeding pattern, caregivers, illness episodes, complimentary feeding

\section{Introduction}

Infants are valuable treasure to the nation. Realizing the importance of child development, United Nations declared 1979 as the International Year of the Child (IYC) and World Health Organisation WHO proposed a theme on World Health Day during 2003 as 'Health Environment for children' and 2005 as ' Make every mother and child count' to focus the attention of planners, policy makers, administrators, health and social scientists on various problems faced by children. Optimal infant and young child feeding (IYCF) practice are crucial for nutritional status, growth, development, health and ultimately. Breast milk is an important source of energy for infants and it provides immunity to fight against illness and reduce mortality. Exclusive breast feeding for six months is an essential component for growth and development of the infant. For children older than six months, breast milk alone is no longer sufficient to meet the nutritional requirement and therefore other foods are needed along with breast milk. Introduction of semi-solid foods after six months is essential to avoid the malnutrition in early life. Globally seven million children, under five years of age died in 2011 and about one fourth $(24 \%)$ of deaths occurred in India. Around $86 \%$ of neonatal deaths arte due to pneumonia, diarrhoea, and preterm births. As per WHO- Child Health Epidemiology Reference Group (CHERG) 2012 estimates, in India the major causes of child mortality in the age group 0-5 years in India are neonatal causes (52\%), pneumonia (15\%), diarrhoeal disease $(11 \%)$, measles $(3 \%)$, injuries $(4 \%)$ and others.

\section{Statement}

A descriptive study to assess the feeding pattern and morbidity pattern among children upto 2 years of age in Daddu Majra Colony, UT. Chandigarh
Objectives

- To study the feeding practices of children upto 2 years of age in Daddu Majra Colony, UT. Chandigarh.

- To study the morbidity pattern in children upto 2 years of age in Daddu Majra Colony, UT, Chandigarh.

\section{Methodology}

A house to house survey was conducted in Daddu Majra Colony to identify subjects. Only children below 2 years of age and their mothers were taken for the study, systemic random sampling method was adopted for the study i.e. every $5^{\text {th }}$ house was surveyed to identify the study subjects. Total 101 subjects were enrolled to collect data related to assess the feeding pattern and mortality pattern among children upto 2 years of age. A written consent was taken from mothers prior to data collection. Data was compiled and analysed using SPSS-16/

\section{Result}

Table 1: Socio demographic Profile of respondents

\begin{tabular}{|l|c|}
\hline Socio-demographic variables & $\mathrm{n}(\%)$ \\
\hline Age in months & \\
$0-6$ & $14(13.9)$ \\
$7-12$ & $37(36.6)$ \\
$13-18$ & $20(19.8)$ \\
$19-24$ & $30(29.7)$ \\
\hline Sex & \\
Male & $60(58.8)$ \\
Female & $41(40.2)$ \\
\hline Religion & \\
Hindu & $91(89.2)$ \\
Muslim & $7(6.9)$ \\
Sikh & $2(2.0)$ \\
Christian & $1(1.0)$ \\
\hline Family type & \\
Nuclear & $52(51.0)$ \\
Joint & $49(48.0)$ \\
\hline Family size & \\
\hline
\end{tabular}

Volume 6 Issue 7, July 2017 www.ijsr.net

Licensed Under Creative Commons Attribution CC BY 
International Journal of Science and Research (IJSR)

ISSN (Online): 2319-7064

Index Copernicus Value (2015): 78.96 | Impact Factor (2015): 6.391

\begin{tabular}{|l|l|}
\hline$\leq 4$ & $38(37.2)$ \\
$5-8$ & $55(54.0)$ \\
$\geq 9$ & $8(7.9)$ \\
\hline No. of rooms & \\
I & $15(14.7)$ \\
2 & $44(43.1)$ \\
3 & $25(24.5)$ \\
$\geq 4$ & $17(16.7)$ \\
\hline Monthly income of parents & \\
$1500-5000$ & $9(8.8)$ \\
$5001-10000$ & $57(55.9)$ \\
$10001-20000$ & $31(30.2)$ \\
$\geq 20000$ & $4(4.0)$ \\
\hline Per capita income & \\
$500-2500$ & $69(67.8)$ \\
$2501-5000$ & $27(26.5)$ \\
$5001-7500$ & $3(2.9)$ \\
$7501-10000$ & $2(2.0)$ \\
\hline
\end{tabular}

Table no. 1 depicts the socio demographic profile of the respondents. Majority of the respondents were in the age group of 7-24 months and more than $50 \%$ were males. Mostly respondents belong to Hindu religion and approximately half lived in nuclear family. More than half of the parents have monthly income in Rs 5001-10000 range.

Table 2: Practices related to feeding pattern of children $\mathrm{N}-101$

\begin{tabular}{|l|l|l|}
\hline S.N & Practice & $\mathrm{n}(\%)$ \\
\hline 1. & Initiation of breast feed & \\
& Within 1 hr & $80(79.2)$ \\
& Within 24 hrs & $15(14.9)$ \\
& After 24 hrs & $5(0.5)$ \\
\hline 2. & Colustrum given to the child & $84(83.2)$ \\
\hline 3. & Prelactal feed given(honey) & $42(41.6)$ \\
\hline 4. & Child exclusively breast feed for 6 months & $74(73.3)$ \\
\hline 5. & Complimentary feeding started & \\
& Before 6 months & $46(45.5)$ \\
& At 6 months & $26(25.7)$ \\
& After 6 months & $26(25.7)$ \\
\hline 6. & Top feed given by & \\
& Katori/spoon & $49(48.5)$ \\
& Bottle & $35(34.7)$ \\
& Cup/sipper & $14(13.9)$ \\
\hline 7. & Breast feed & \\
& Continued & $84(83.2)$ \\
& Terminated - at 6 months & $3(3.0)$ \\
& & $9(8.9)$ \\
& & $5(5.0)$ \\
\hline 8. & Most preferred food by child & \\
& Sweet & $28(27.7)$ \\
& Salty & $60(59.4)$ \\
\hline 9. & Registerd at anganwadi & $99(98.0)$ \\
\hline 10. & Anganwadi food given to child & $55(54.5)$ \\
\hline 11. & Reason for not giving anganwadi food & $8(7.9)$ \\
& Longer distance & $10(9.9)$ \\
& Shortage of time & $7(6.9)$ \\
& Disliked by child & $11(10.9)$ \\
\hline & Not preferred by mother & \\
\hline
\end{tabular}

Table No. 2 represents practices related to feeding pattern of children. Approximately $80 \%$ of mothers initiated breastfeed to children with in 1 hour of birth. Nearly $40 \%$ of the mothers gave prelacteal feed to babies. $3 / 4^{\text {th }}$ of mothers exclusively breast feed their child for 6 months and nearly half of the children were given complimentary feeding before 6 months. $50 \%$ of the child got top feed by katori/spoon. More than $1 / 2$ of the children like salty food and $99 \%$ were registered at anganwadi. Only $50 \%$ of the mothers gave anganwadi food to child.

Table 3: Morbidity pattern in children below 2years of age, N-101

\begin{tabular}{|l|l|l|}
\hline S. No. & Practice & $n(\%)$ \\
\hline 1. & Birth Weight & \\
& $1.5-2.0$ & $1(1.0)$ \\
& $2.1-2.5$ & $37(36.6)$ \\
& $2.6-3.0$ & $20(19.8)$ \\
& $3.1-3.5$ & $30(29.7)$ \\
\hline 2. & Immunization Status & \\
& Complete & $100(99.0)$ \\
& Incomplete & $1(1.0)$ \\
\hline 3. & Place of Delivery & \\
& Hospital & $97(96.0)$ \\
& Home & $4(4.0)$ \\
\hline 4. & Problem occurred to child at the time of birth & $25(24.8)$ \\
\hline 5. & Frequently occurring morbidity & \\
& Diarrhoea & $21(20.8)$ \\
& ARI & $29(28.7)$ \\
& Conjuctivitis & $2(2.0)$ \\
\hline
\end{tabular}

Table no.3 depicts morbidity pattern in children below 2 years of age. Data revealed that more than half of the children have normal birth weight. More than $90 \%$ of the children were delivered in hospital and were immunized. $1 / 4^{\text {th }}$ of the children suffered from health problems at the time of birth. The more frequently occurring morbidities to children were Diarrhoea, ARI's as compared to conjunctivitis.

Table 4: Health Problems in children, N-101

\begin{tabular}{|c|c|c|c|c|}
\hline \multirow{2}{*}{ Health Problem } & \multicolumn{4}{|c|}{ Age of child } \\
\cline { 2 - 5 } & $\begin{array}{c}<1 \\
\text { month }\end{array}$ & $\begin{array}{c}1-6 \\
\text { months }\end{array}$ & $\begin{array}{c}6-12 \\
\text { months }\end{array}$ & $1-2$ year \\
\hline Diarrhoea & $8(7.9)$ & $23(22.8)$ & $28(27.7)$ & $20(19.8)$ \\
\hline ARI & $3(3.0)$ & $15(14.9)$ & $3(3.0)$ & $1(1.0)$ \\
\hline Fever & --- & $2(2.0)$ & $4(4.0)$ & $11(10.9)$ \\
\hline $\begin{array}{c}\text { Diarrhea,Fever, } \\
\text { Cold }\end{array}$ & --- & $8(7.9)$ & $7(6.9)$ & $1(1.0)$ \\
\hline Diarrhea,Fever & --- & --- & $1(1.0)$ & $6(5.9)$ \\
\hline Conjunctivitis & --- & ---- & $6(5.9)$ & -- \\
\hline Ear Infection & --- & $2(2.0)$ & $2(2.0)$ & --- \\
\hline Jaundice & $25(25.8)$ & ---- & ---- & --- \\
\hline
\end{tabular}

Table no.4 revealed the health Problems in children among different age groups. It has been seen that diarrhoea and ARI's frequently occurring health problem in every age group. It also observed that $28 \%$ of children between $6-12$ months of age suffered from diarrhoea while $15 \%$ of children between 1-6 months of age suffered from ARI's. $1 / 4^{\text {th }} \%$ age of children below one month of age suffered from Jaundice.

\section{Major Findings of the Study}

Results of the study concluded that the majority of the delivery took place in hospital and mothers initiated breast feeding within one hour of delivery and approx. Half of the caregivers give prelacteal feed to the child. Complementary feeding was started at or after 6 months of age of the child. Majority of the children birth weight was in normal range and $1 / 4^{\text {th }}$ of the child suffered from problem, mainly

\section{Volume 6 Issue 7, July 2017 www.ijsr.net}




\section{International Journal of Science and Research (IJSR) \\ ISSN (Online): 2319-7064}

Index Copernicus Value (2015): 78.96 | Impact Factor (2015): 6.391

jaundice at the time of birth. Frequently occurring morbidities in children were diarrhoea, acute respiratory tract infections and conjunctivitis.

\section{Conclusion}

It has been concluded from the study that a few of the mothers were not following the feeding practices accurately which affects the health of the children \& Diarrhoea and ARI's were the most frequently occurring morbidities among the children under 2 years of age.

\section{Recommendations}

1) An experimental study can be done to assess the effectiveness of Behavioural change practices among mothers for the prevention of Diarrhea among children below 2 years of age.

2) A study can be done to the educate the mothers /caregivers to improve the feeding practices of children under 2 years of age.

\section{References}

[1] Aggarwal A, Verma S, Faridi MMA, Dayachand. Complementary feeding reasons for inappropriateness in timing, quantity and consistency. Indian $\mathrm{J}$ Pediatr. 2008;75:49-53. [PubMed]

[2] World Health Organization. Complementary feeding Report of the global consultation Summary of Guiding principles Geneva. 2001.

[3] The breast feeding promotion network of India. Introducing solids (Complementary Feeding) Available from: http://www.bpni.org/breastfeeding/intro complementry_feeding.

[4] Cohen RJ, Rivera LL, Canahuati J, Brown KH, Dewey KG. Delaying the introduction of complementary feeding until 6 months. J Nutr. 1995;125(11):2787-92. [PubMed]

[5] Kapur D, Sharma S, Agarwal KN, Dietary intake and growth pattern of children 9-36 months of age in an urban slum in Delhi. Vol. 42. Indian Pediatr: 2005. pp. 351-356. [PubMed] 